\title{
The Application of Authorware to the English Teaching in the Multimedia Environment
}

\author{
Tian Xu \\ English Department, Foreign Languages School \\ Harbin University of Science and Technology \\ Harbin, China \\ besttx@sohu.com
}

\begin{abstract}
The development of multimedia technology in computer science enriches the traditional English teaching methods. As soon as the new technology applies to the English teaching, it arouses the attention and is welcomed by the English teaching professors both abroad and at home. At present, the multimedia soft wares are widely applied to the English teaching, which has fully realizes the human-computer interaction. Among those soft wares, authorware brings enormous advantages for the English teaching and study for both the teachers and the students. In this essay, that authorware is applied to the English teaching is discussed.
\end{abstract}

Keywords-multi-media, human-computer interaction, authorware, English teaching

\section{INTRODUCTION TO THE AUTHORWARE}

Authorware is a multimedia production software which is developed by Macromedia in America. There are two versions in the Windows environment, which are Authorware Professional and Authorware Star. Authorware is a multimedia production tool with icon orientation, which makes it possible for the non-professionals to develop multimedia software quickly. The powerful functions of authorware are marvelous, namely: powerful integration ability, powerful interaction ability, vivid, explicit and easy development interface, full extensible ability and perfect network support. Authorware has strong ability of human-computer interaction, which offers 11 interaction means, basically satisfying the various needs for different users.

\section{THE APPLICATION OF AUTHORWARE TO ENGLISH TEACHING}

Authorware can be used in English teaching, such as the basic teaching of listening, speaking, reading and writing, even the teaching of literature, linguistics and translation. Authorware is an easy software, which can be mastered by the English teachers who want to produce the multimedia software in the English class in order to arouse the students' interest.

\section{A. The Manufacture of Homepage}

When producing the teaching software by Authorware, first of all, we can put a display icon on the flow line, on which background pictures can be inserted. After inserting the background pictures, we can set the special effects we prefer or we think it suitable for the teaching contents according to the teaching plan. Then the word scripts can be

\author{
Lv Yanling \\ Electrical Engineering School \\ Harbin University of Science and Technology \\ Harbin, China \\ 22185968@qq.com
}

added, for example, in English writing teaching, several levels of samples can be added for the students to appreciate or criticize. Finally, the necessary control buttons are set in accordance with the teaching design.

\section{B. The Design of the Flow Line}

Before the teacher starts making the courseware by Authorware, he or she is suggested to show the course content by a flow line. For instance, when does the content begin? Where does the content go on? And how can the content return back to the previous one? It is preferred to make sure the content of the teaching and design a suitable flow line. The flow line designed by Authorware can explicitly and directly show the teaching plan, teaching content and teaching aim both for the teacher and the students.

Put the display icon and wait icon on the flow line one by one, and number them to edit the subsequent content. For instance, if the writing teacher wants to give several samples to the students to appreciate, he or she can insert the display icon on the flow line and click the display icon, then on the left appears tools column, in which he/she can click A to insert the text samples. If the teacher wants to add some sounds or videos, then he/she can insert the sound icon or visual icon on the flow line, then choose the suitable files in the computer or on the internet. See the figure 1.

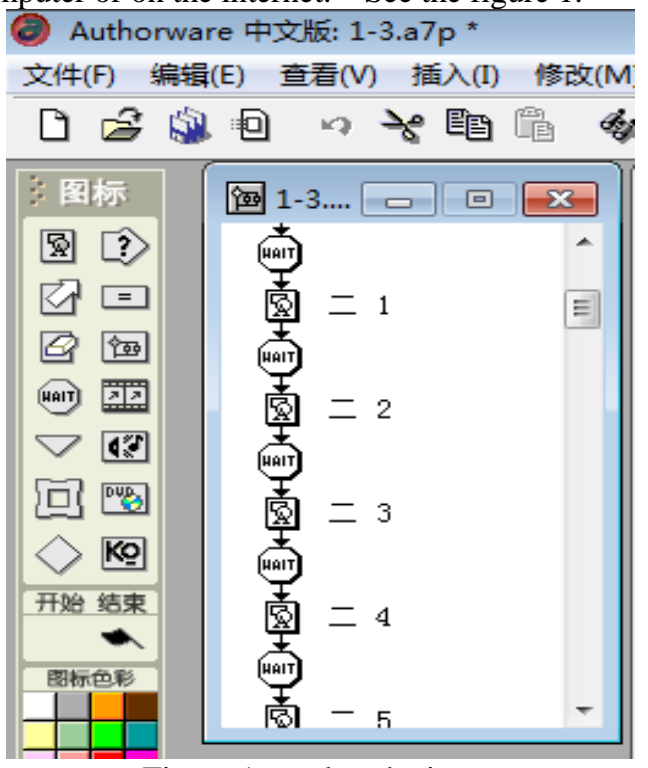

Figure 1 number the icons 
Between the two icons, there should be a wait icon which can be used as a control button when displaying the multimedia software. The teacher had better set the attribute of the wait icon as clicking the mouse in order to control the process of the courseware. See figure 2 .

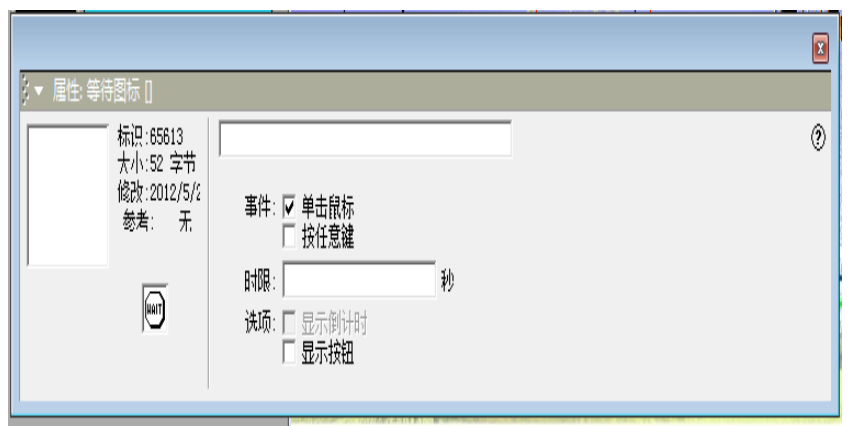

Figure 2 setting the attribute of wait icon

The mobile icon can help realize the various flash effects of texts or pictures, so in this way during the process of learning, students' senses and learning interests are fully stimulated, and their imagination and creation ability can be performed in a wider environment. Among the five mobile types, the first two types (namely, pointing to the fixed point and pointing to a certain point in the fixed line) are commonly used in producing the courseware when the texts or pictures need to be moved.

\section{Insert the Content of Every Chapter}

Authorware can provide the easy text input and painting, and can set the text input mode in the menu column, for the alternate use of several texts to make the content have the sense of levels. For instance, in the English writing class, the teacher can input the excellent samples as the text, so when the students read these samples, they can have a new feeling and expect the various ways to present the samples by the Authorware. Therefore, students' writing desire can be stimulated. If there are some complicated pictures, words or some others which can help the teaching, click the insert to set the pictures in the Authorware interface.

\section{Powerful Human-Computer Interaction Ability}

Authorware provides 11 methods for human and computers to interact so as to satisfy the needs of various teaching modes and design. A good case in this point is that in the English listening course, as to the difficult part for most of the students, the teacher can use Authorware to repeat, slow down or some other special ways to strengthen the listening comprehension of the students. The same is as in the writing class, after the teacher illustrates the writing theories and skills, students can be guided to input the text to write their own paragraphs or compositions, which can be criticized by the teacher, classmates or by themselves. Such design method conforms to the teaching process, at the same time, improves the interests of the students and enhances the learning efficiency.

\section{E. The Package of the courseware}

The package of the courseware, simply speaking, is to convert what the teacher has already done on the Authorware to the executive programs, which can be run independently away from the Authorware environment. When packaging the multimedia works, not only the main program is imperative, some other supportive programs should also be necessary, such as, DLL file, Xtras file, or some other media files. The coursework can not run normally if some necessary files do not exist. It is necessary to notice that after the package of the courseware, others can not find out the source programs in the courseware so as to protect the courseware.

If the teacher wants to run the courseware in the computer without installing the Authorware, he or she should package the courseware to an exe. File which can be run independently in the environment of Windows series.

\section{THE ADVANTAGES THAT AUTHORWARE BRINGS TO THE MODERN ENLGISH TEACHING}

In the present day English teaching, multimedia technology is widely used in the English classroom, in China, almost all the universities provide the special fund for the development of the multimedia classroom, especially in the English classroom. Therefore, English teachers would utilize the multimedia technology to teach English class, such as listening, speaking, reading, writing, translation, literature, culture and some other courses. There are enormous advantages for the teachers and students when their class is filled with Authorware.

\section{A. It Enriches the Course Content}

The English teachers can make full use of multimedia technology, such as Authorware, to combine text, graphs, sounds, flash, videos and some other multimedia data together, and students can study the various materials presented by multimedia technology. Under such circumstances, the traditional situation of students passively accepting knowledge has been changed. In the information era based on the networks, teaching resources are fully used in the foreign language teaching, so the class content is highly enriched.

\section{B. It Enhances the Learning Efficiency}

Compared with the traditional teaching mode, the modern class infused with multimedia technology, for example, Authorware, embraces the beautiful pictures, soft music and even funny flash, stimulating the students' senses from all the aspects. Therefore, the lively teaching atmosphere is created, and at the same time, the tension and fatigue which is produced when students are listening to the lecture is relieved. As a result, students can acquire knowledge actively in a perfect condition, and excellent teaching results can be achieved. On the other hand, the courseware based on Authorware can save the time when the teachers spend on writing on the blackboard, so the class efficiency is much enhanced. 


\section{It Improves the Relationship between Teachers and Students}

In the modern classroom, thanks to the application of multimedia technology, students are not the passive receivers of the knowledge. Based on the courseware manufactured by Authorware, students can preview the learning materials before the class begins and review what they get from the classroom, so teachers are not the dominators in the class. In most of English classrooms, the relationship between teachers and students is more harmonious and equal. They can share their views in the class or after class by using of the courseware.

\section{It Is Easy for the Teachers to Operate}

Although most of English teachers have already attended the computer technology training and they have already mastered some computer operations, they, after all, are not professional computer technicians. Compared with other computer softwares, Authorware can provide easy operations for the non-professionals. It enables to combine the graphs, text, sound, videos and flash together to form a perfect multimedia system. As long as the English teachers download the Authorware, they can make courseware according to the guidance, which is particularly convenient. It does not require the English teachers to have top computer knowledge, and its appearance makes it possible that English teachers can manufacture multimedia courseware with high quality in the English teaching class.

\section{E. It Traces the Progress and Results of the Students}

Compared with the traditional teaching, modern education is more student-oriented and pays more attention to the learing effects of the students. Authorware can design the teaching process according to the teaching aim and the rhetorical situation of the students, arrange the necessary practice, guide the students to explore in the study independently to improve their self-learning ability. On the other hand, teachers can trace the process and speed of the students according to the students' feedback, so as to find out the learning problems of the students during their studying process.

\section{THE POTENTIAL DRAWBACK THAT AUTHORWARE MAY BRING TO ENGLISH TEACHING}

It is no surprising to notice that it is the merits of drawing students' attention that convert to the drawbacks of it in the classroom. In most of the cases, what attracts the students is not the teaching content itself, but the multimedia technology. The students' attention could be attracted by the pictures, sounds, music, flash or some other multimedia, but they can not turn their attention back on the study at the due time. Therefore, their attention is much more focused on the courseware based on the Authorware, resulting in their neglect of the important class.

\section{CONCLUSION}

Multimedia has stepped into our foreign language teaching at a rapid and unexpected speed, so that the teaching information increases enormously in our language teaching and the quality has been improved. As one of the multimedia technology software, Authorware brings so many benefits to our language teaching that the course content is enriched, the learning enthusiasm is highly stimulated, and the condition for the students' self-study is provided. However, in the meanwhile, we should be aware that it may bring the potential drawbacks to our language teaching.

\section{REFERENCES}

[1] Gao Zhiqing, "The basis and improvement of Authorware 7.0 multimedia courseware manufacture", Beijing: China Hydropower Press, 2006, pp. 67-76.

[2] Jian Ping, Wu Lihua, and Liu Ruohui, "The Manufacture of CAI courseware”, Beijing: The People's Posts and Telecoummunications Press, 2008, pp 32-89

[3] Tan Haoqiang, "The creation and application of multimedia courseware”, Beijing: Machinery Industry Press, 2002, pp 36-66

[4] Zhang Yunlin, “The practical course of Authorware”, Beijing: Peking University Press, 2011, pp 56-68

[5] Liu jingli, "Developing the bilingual teaching courseware by Authorware”, Modern Electron Technology, vol. 173, June. 2004, pp. 57-59

[6] Ju jie, "The application of Authorware teaching courseware," Technology Information, Mar. 2009, pp. 22-23

[7] Wang Lizhong, Yu yunyan, Bao Yadan, "The application of Authorware in the multimedia bilingual teaching," The Journal of China Nationality University, vol. 17, Feb, 2008, pp. 90-92 